\title{
EQUILIBRIUM AMMONIUM CONCENTRATION IN SLURRY MIX EVAPORATOR CONDENSATE TANK (SMECT) WITH AMMONIA SCRUBBERS (U)
}

\author{
by D. P. Lambert \\ Westinghouse Savannah River Company \\ Savannah River Site \\ Aiken, South Carolina 29808 \\ Other Authors:
}

\author{
WSRC-RP--92-1163 \\ DE93 006881
}

\section{DISCLAIMER}

\begin{abstract}
This report was prepared as an account of worki sponsored by an agency of the United States Government. Neither the United States Government nor any agency thereof, nor any of their employees, makes any warranty, express or implied, or assumes any legal liability or responsibility for the accuracy, completeness, or usefulness of any information, apparatus, product, or process disclosed, or represents that its use would not infringe privately owned rights. Reference herein to any specific commercial product, process, or service by trade name, trademark, manufacturer, or otherwise does not necessarily constitute or imply its endorsement, recommendation, or favoring by the United States Government or any agency thereof. The views and opinions of authors expressed herein do not necessarily state or reflect those of the United States Government or any agency thereor.
\end{abstract}

This paper was prepared in connection with work done under Contract No. DE-AC09-89SR18035 with the U. S. Department of Energy. By acceptance of this paper, the publisher and/or recipient acknowledges the U.S. Government's right to retain a nonexclusive, royalty-free license in and to any copyright covering this paper, along with the right to reproduce and to authorize others to reproduce all or part of the copyrighted paper.

\section{MASTER}

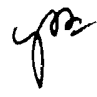




\section{DISCLAIMER}

This report was prepared as an account of work sponsored by an agency of the United States Government. Neither the United States Government nor any agency thereof, nor any of their employees, makes any warranty, express or implied, or assumes any legal liability or responsibility for the accuracy, completeness, or usefulness of any information, apparatus, product, or process disclosed, or represents that its use would not infringe privately owned rights. Reference herein to any specific commercial product, process, or service by trade name, trademark, manufacturer, or otherwise does not necessarily constitute or imply its endorsement, recommendation, or favoring by the United States Government or any agency thereof. The views and opinions of authors expressed herein do not necessarily state or reflect those of the United States Government or any agency thereof.

This report has been reproduced directly from the best available copy.

Available to DOE and DOE contractors from the Office of Scientific and Technical Information, P. O. Box 62, Oak Ridge, TN 37831; prices available from (615) 576-8401.

Available to the public from the National Technical Information Service, $U$. $S$. Department of Commerce, 5285 Port Royal Rd., Springfield, VA 22161. 
C. T. Randall, 704-T

M. J. Plodinec, 773-A

L. F. Landon, 704-T

SRTC Records (4)

September 25, 1992

TO: J. T. CARTER, 704-1T

EROM: D. P. IAMBERT, 704-1Tthentalf

\section{Equilibrium Ammonium Concentration in SIurry Mix Evaporator Condensate Tank (SMECT) with Ammonia Scrubbers (U)}

\section{INTRODUCTION:}

The original calculation [1] of the maximum batch ammonium concentration did not take into account the chemical neutralization in the Recycle Collection Tank (RCT). During design reviews it was determined that in all cases the RCT scrub solution could not be routed to the RCT. During transfers to the tank farm (estimated ten hour cycle), the ammonia evolved from the RCT is scrubbed by the RCT scrubber and the ammonia scrub water must be returned to the SMECT. The result of this is an increased steady state concentration of ammonium in the SMECT water used for the ammonia scrubbers. The maximum ammonium concentration is necessary for the sizing of the ammonia scrubbers for the sludge Receipt and Adjustment Tank (SRAT), Slurry Mix Evaporator (SME), and RCT. Figure 1 is a simplified schematic of the ammonia scrubbers.

\section{SUMMARY:}

The equilibrium ammonium concentration in the SMECT is 0.0015 mole fraction ammonium. This water is chemically adjusted to $\mathrm{pH} 3.0$ and used for the scrub solution in the ammonia scrubbers. A mass balance (Table 1) was completed using the volume transfers made by the batch model for the SMECT and RCT [2]. The ammonia content of the Precipitate Hydrolys is Aqueous (PHA) was determined experimentally in IDMS using the PHA produced using the HAN process (higher in ammonium than PHA produced using the late wash process).

The higher equilibrium ammonium concentration will be controlled by the used of excess acid in the SMECT to lower the $\mathrm{pH}$ to 3.0 . The effect of the higher ammonium 

J. T. CARTER
Page 2
WSRC-RP-92-1163

concentration i minimal since the ammonia concentration is controlled by $s$.ting with a $\mathrm{pH}$ of 3.0 . A model of the scrubber ammonia profile was estimated using the OII ELECTROCHEM version 9.0 electrolytic chemical modeling program [3]. A summary of the data for a starting point of $\mathrm{pH} 3.0$ and ammonium concentration of 0.0015 is summarized in Eigures 2 and 3 . These figures are a replacement for Eigures 3 and 4 in the original document [1]. The effect on the design of the scrubbers should be minimal and can be controlled by a lower starting $\mathrm{pH}$ than the 3.0 that was specified to minimize corrosion problems.

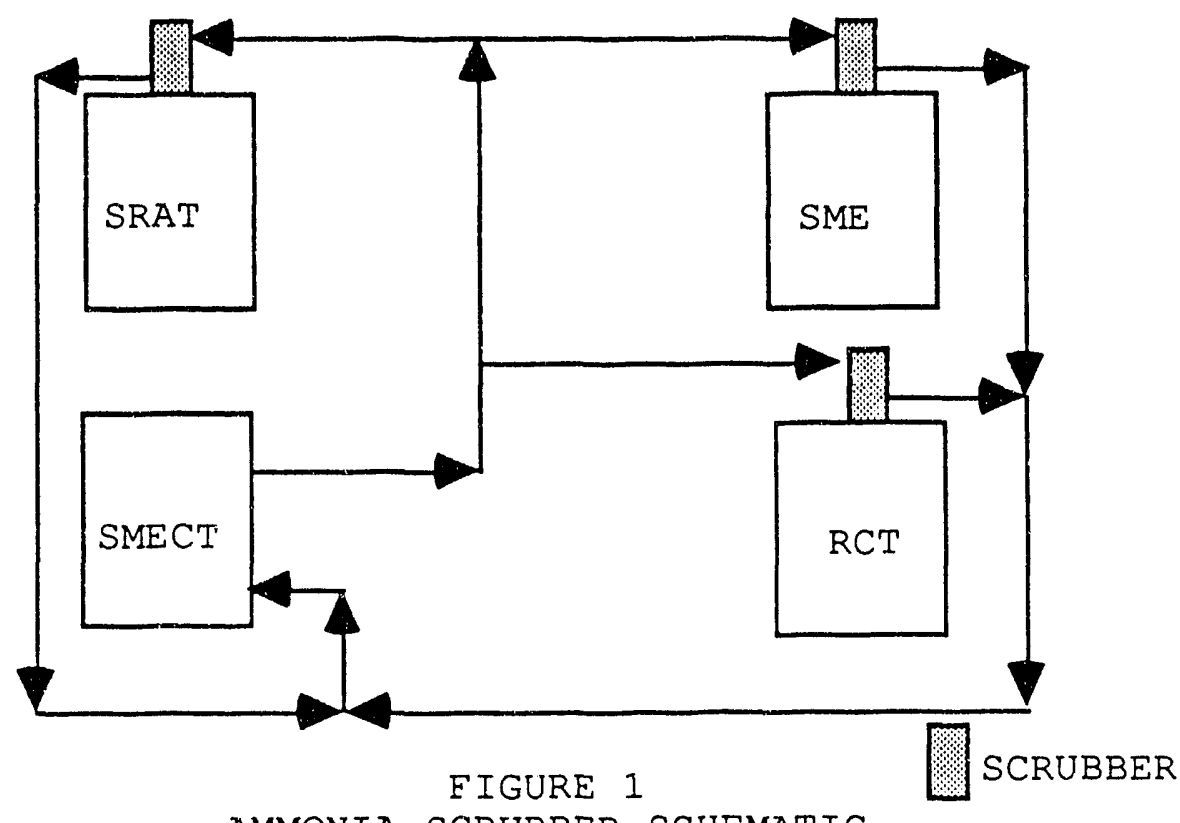

AMMONIA SCRUBBER SCHEMATIC

\section{References}

1. J. T. Carter, D. P. Lambert, A. S. Choi, WSRC-TR-92-296, Revised Basis and Calculation Methods for the DWPF Ammonia Scrubbers (U), June 20, 1992.

2. R. E. Edwards, WSRC-92-0159, Assessment of DWPF Batch Cycle Times Using the DWPF Batch Simulation Program (U), March 16, 1992.

3. A. S. Choi, Ammonia scrubber model using OLI ELECTROCHEM Version 9.0, September 22, 1992. 

I. T. CARTER
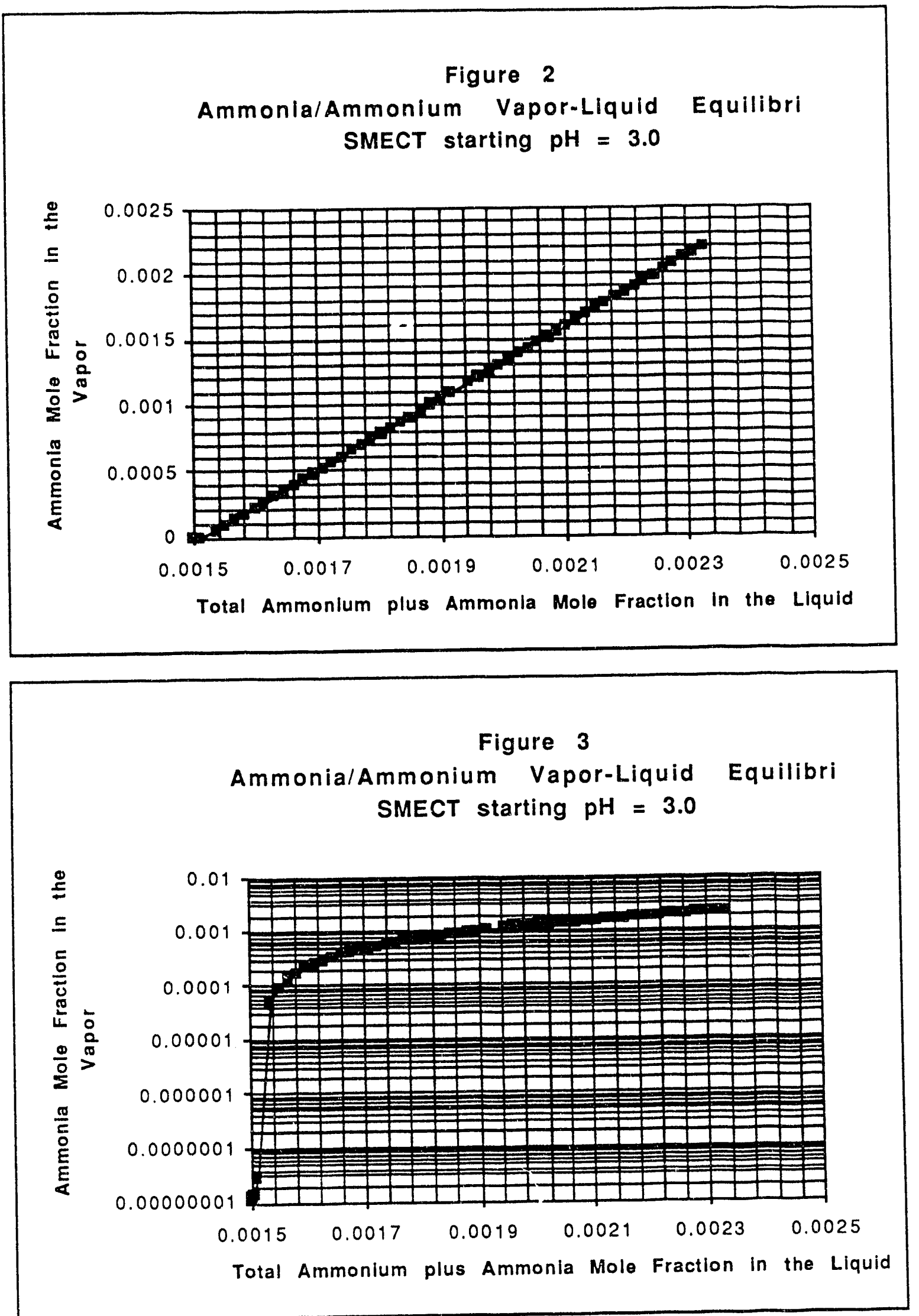


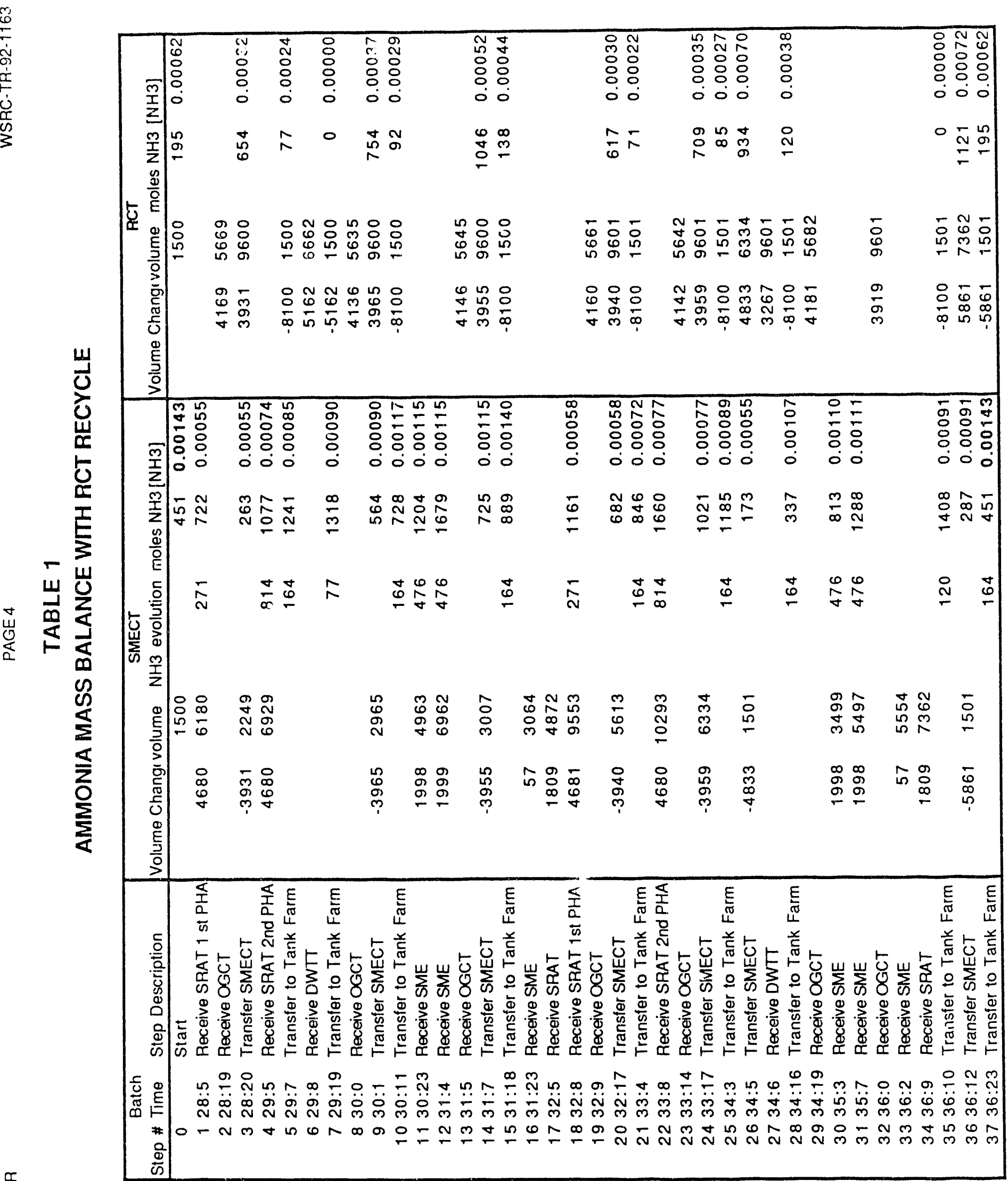



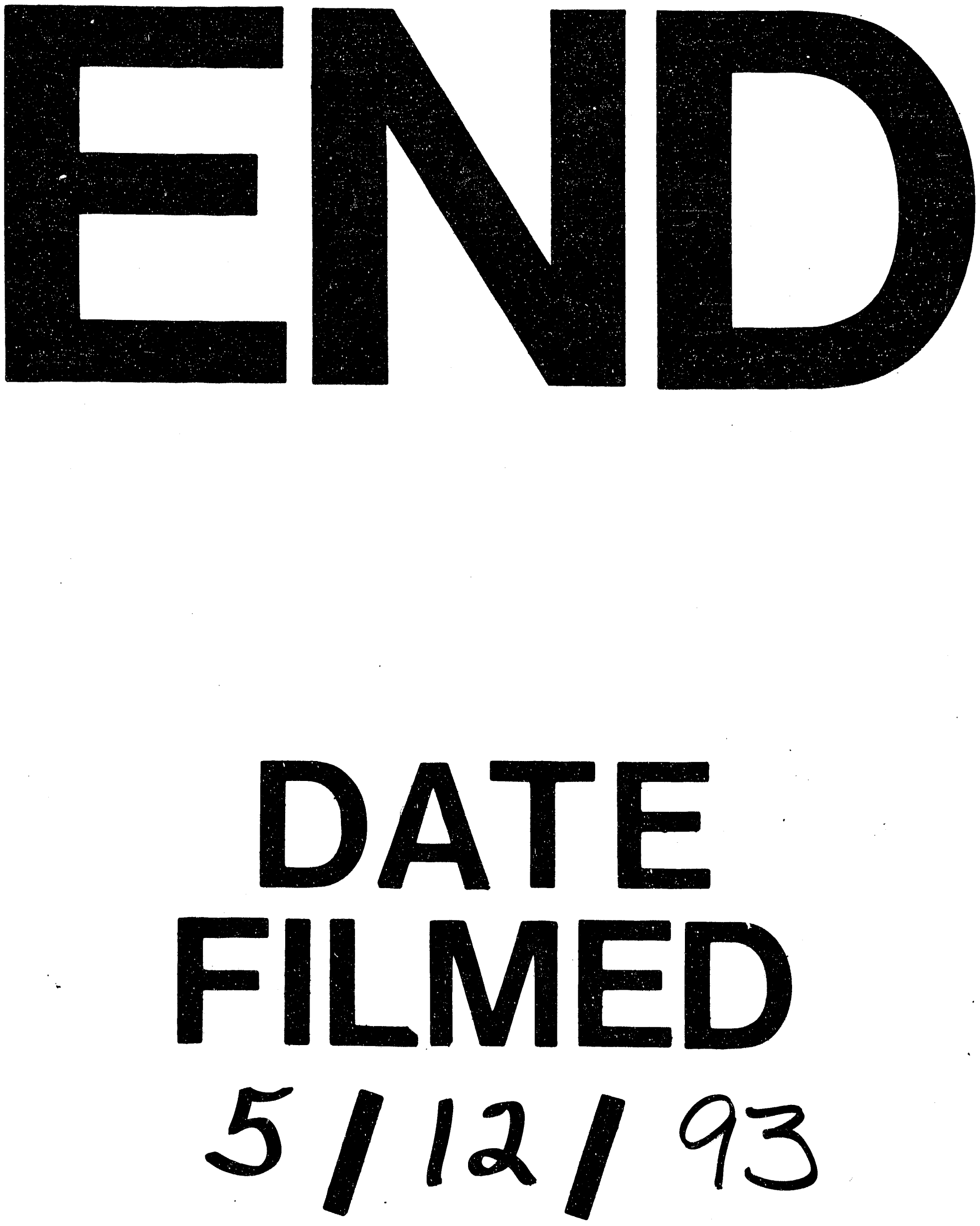
